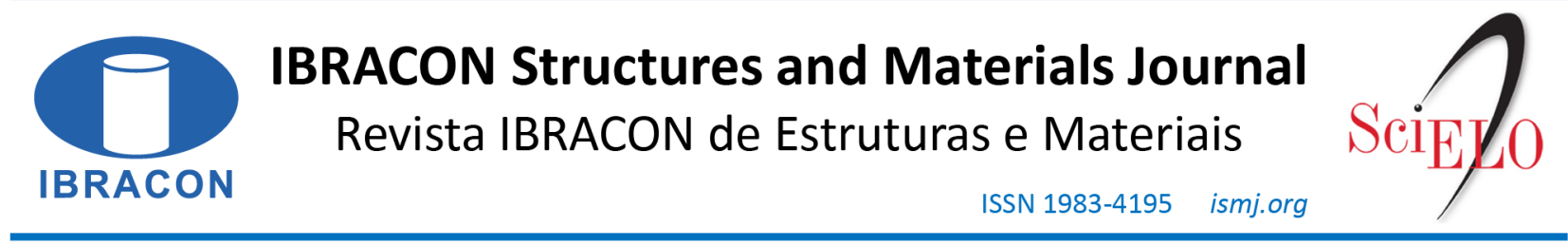

ORIGINAL ARTICLE

\title{
Degradation of the EBR-CFRP strengthening system applied to reinforced concrete beams exposed to weathering
}

\author{
Degradação do sistema de reforço EBR-CFRP em vigas de concreto armado \\ expostas ao intemperismo
}

\author{
Gláucia Maria Dalfréa (D) \\ Guilherme Aris Parsekian ${ }^{\mathrm{a}}$ (1) \\ Douglas da Costa Ferreira ${ }^{a}$ (iD
}

${ }^{a}$ Universidade Federal de São Carlos - UFSCar, Programa de Pós-graduação em Engenharia Civil, São Carlos, SP, Brasil

Received 16 January 2020

Accepted 08 July 2020

\begin{abstract}
Little is known about the behavior and durability of strengthening systems applied on concrete substrata and the possible loss of performance due to the degradation of the intervening materials by the structure's natural aging process and exposure of the externally strengthened elements to aggressive environments. In this context, the present work presents an experimental analysis of the behavior of reinforced concrete beams strengthened with Carbon Fiber Reinforced Polymer (CFRP), applied according to the Externally Bonded Reinforcement (EBR) technique, maintained in a laboratory environment (indoor and protected) or exposed to weathering (outdoor exposure). In addition, specimens of the intervenient materials were also molded and exposed to the same environmental conditions as the beams. The results indicate that weather-exposed epoxy adhesives present reductions up to $70 \%$ in their mechanical properties after exposure, while the CFRP composite properties remain similar. It was also found that the strengthening system provided $50 \%$ and $28 \%$ increments in the load-carrying capacity and stiffness of the elements, respectively. However, the tests conducted after 6 months of weathering exposure showed a $10 \%$ reduction in the load-carrying capacity of the strengthened elements.
\end{abstract}

Keywords: reinforced concrete beams, strengthening, CFRP, degradation, EBR technique.

Resumo: Pouco se sabe a respeito do comportamento e da durabilidade do sistema de reforço aderido ao substrato de concreto e a possível perda de desempenho frente à degradação dos materiais intervenientes face ao processo natural de envelhecimento das estruturas e, também, devido à exposição dos elementos reforçados externamente a ambientes agressivos. Neste âmbito, o presente trabalho baseia-se na análise experimental do comportamento de vigas de concreto armado reforçadas a flexão com mantas de fibra de carbono (CFRP, Carbon Fiber Reinforced Polymer) aplicadas segundo a técnica EBR (Externally Bonded Reinforcement) mantidas em ambiente laboratorial (interno e protegido) e expostas a intempéries (exposição exterior). Para além disso, corpos de provas dos materiais constituintes do sistema de reforço também foram confeccionados e expostos nas mesmas condições ambientais das vigas. Os resultados demonstraram que os adesivos epoxídicos apresentam reduções de até $70 \%$ em suas propriedades mecânicas quando expostos às intempéries enquanto o compósito de CFRP permanece com suas propriedades inalteradas após mesma exposição. Para as vigas de concreto armado reforçadas, foi verificado que o sistema de reforço proporciona incrementos de 50 e $28 \%$ na capacidade de carga e rigidez dos elementos reforçados, respectivamente. No entanto, os ensaios realizados após 6 meses de exposição às intempéries demonstraram uma redução de $10 \%$ no incremento da capacidade de carga dos elementos reforçados.

Palavras-chave: vigas de concreto armado, reforço, CFRP, degradação, técnica EBR.

How to cite: G. M. Dalfré, G. A. Parsekian, and D. C. Ferreira, "Degradation of the EBR-CFRP strengthening system applied to reinforced concrete beams exposed to weathering”, Rev. IBRACON Estrut. Mater., vol. 14, no. 2, e14208, 2021, https://doi.org/10.1590/S1983-

41952021000200008

Corresponding author: Gláucia Maria Dalfré. E-mail: glaucia.dalfre@ufscar.br

Financial support: Coordination for the Improvement of Higher Education Personnel (CAPES).

Conflict of interest: Nothing to declare. 


\section{INTRODUCTION}

Strengthening a structural element means restoring or increasing its supporting conditions in relation to those for which it was initially designed. Carbon Fiber Reinforced Polymer (CFRP) strengthening systems can be applied to various reinforced concrete elements such as beams, columns, slabs. Design errors, project reading misinterpretation, changes in the structure use, or the natural weathering of buildings are some of the main reasons for strengthening a structure [1].

Among the main materials used for this purpose, Fiber Reinforced Polymers (FRPs) are of high prominence because their mechanical properties are superior to the conventional materials used in strengthening techniques. Of the main characteristics of FRPs, high strength and stiffness, and low weight are the main properties that favor their use in strengthening works [2].

CFRPs are the most widely used materials for structural strengthening [3]. One main advantage of CFRPs is the resistance to chemical agents and corrosion [4]. According to Barros [5], prefabricated and in-situ cured systems are the most used in strengthening techniques. Prefabricated systems are supplied in the form of laminates or circular section bars, with their fibers oriented in the longitudinal direction of the element. In-situ cured matrix and fiber are supplied separately, and CFRP composite manufacturing is carried out at the strengthening application site. In this case, the fibers may be either unidirectional or bidirectional in orientation and supplied in the form of sheets or fabrics.

Of the various ways of applying strengthening systems, the Externally Bonded Reinforcement (EBR) technique is widely used. It originated in Europe, proposed and developed in Switzerland, and it was first used to strengthen a bridge using CFRP sheets in the city of Lucerne in 1991. Since then, the EBR technique has continued to be used in strengthening interventions [6], [7] due to its advantages, such as the ease of application and good mechanical performance [8].

Further, the EBR technique allows for increments in bending with the bonding of the strengthening system on the tensile face of the beams, or even by shear, by strengthening the lateral faces of the beams, or with the strengthening systems working simultaneously.

According to Karbhari [9] and Gangarao et al. [10], composite materials used in civil construction can be exposed to various aggressive agents. Determining the effects of environmental aggressiveness on the adhesion of the concreteadhesive FRP, especially over prolonged periods, is of extreme importance [11]. There is a need for further knowledge of their long-term performance, durability, and design life in the face of conditions such as moisture, seawater salinity, and thermal cycles, among others.

The present work aimed to evaluate the long-term durability and mechanical behavior of the flexural strengthening system's constituent materials, as well as reinforced concrete beams strengthened with CFRP, applied according to the EBR technique, maintained in a laboratory environment (internal and protected) or exposed to weathering (outdoor exposure).

\section{STATE OF THE ART}

\subsection{Degradation of FRPs when exposed to weathering}

All materials used in the construction industry are subject to degradation, originated by chemical, physical, or mechanical sources. Applying an FRP strengthening system to a determined concrete element, these degradation mechanisms should be considered to achieve better long-term behavior and durability [12]. Degradation mechanisms can occur either individually or together in the degradation of the composite FRP material (Figure 1).

It is generally known that degradation mechanisms directly affect the most sensitive part of the strengthened structure, i.e., the bond between the concrete substrate and the FRP composite. Bonding usually relies on epoxy-based resins, which are susceptible to degradation in harsh environments. These resins are susceptible to ultraviolet (UV) radiation, temperature, humidity, and acid rain [13]. Unless a protective layer is used, the FRP gets directly exposed to the external environment and, consequently, to the possible aggressive agents or eventualities, as shown in Figure 2.

Direct exposure to UV radiation from polymers can result in photodegradation, a mechanism that causes the decomposition or dissociation of chemical bonds between polymer chains, driven by the UV radiation present in solar waves. This radiation causes the degradation of polymers, leading to discolouration, surface oxidation, embrittlement, and polymer matrix microfissuration [12]. 


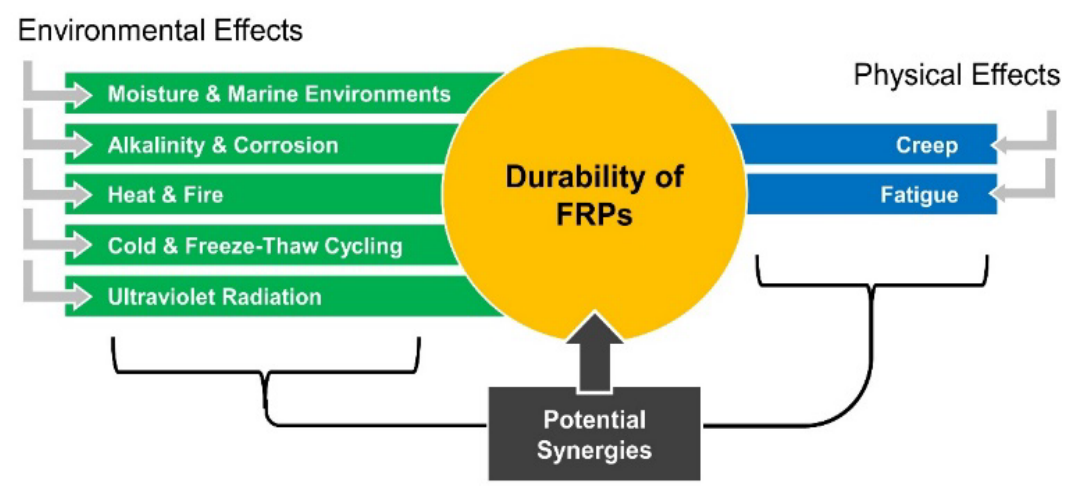

Figure 1. Degradation mechanisms of FRP systems [12]

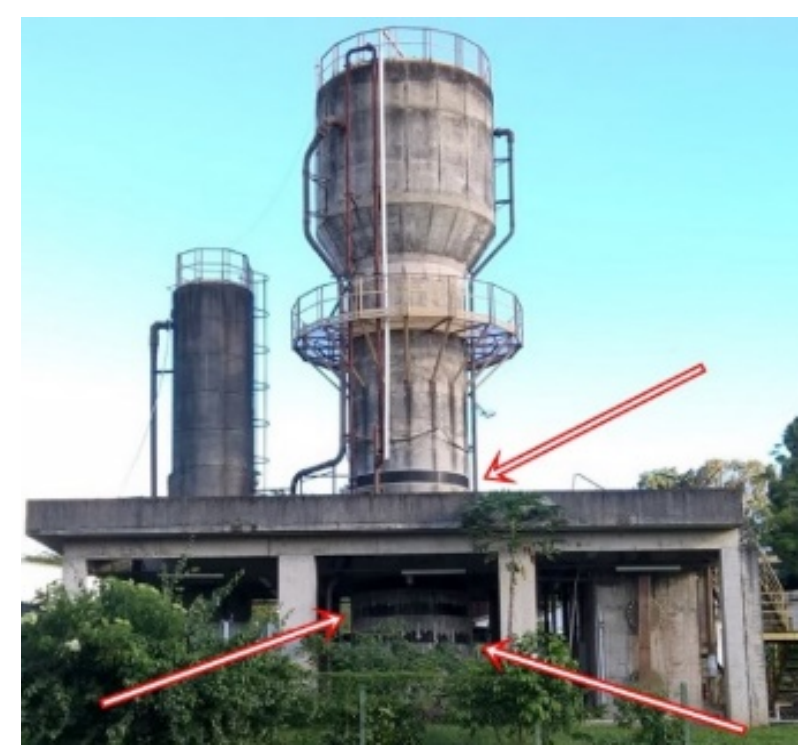

Figure 2. Sewage station with CFRP sheets externally applied according to the EBR technique [14]

Zhao et al. [15] evaluated three types of degradation in polymeric resins (ester-vinyl, epoxy, and epoxy ester) when exposed to UV radiation. In the study, specimens with $200 \mathrm{~mm}, 20 \mathrm{~mm}$, and $4 \mathrm{~mm}$ in length, width, and thickness, respectively, were prepared and cured for seven days at room temperature. Subsequently, they were exposed to UV radiation $(280-315 \mathrm{~nm})$ at a temperature of $57-63^{\circ} \mathrm{C}$ and humidity of $90-95 \%$. The radiation cycles lasted 12 hours ( 8 hours of UV radiation and 4 hours of condensation) for a total period of 90 days (Table 1). The ester-vinyl resin presented higher degradation, with a reduction of $65 \%$ and $69 \%$ in tensile strength and modulus of elasticity, respectively. After exposure, the resin specimens presented significant changes in their colouration.

Table 1 Mechanical properties of resins after exposure to UV radiation [15]

\begin{tabular}{|c|c|c|c|c|c|c|}
\hline \multirow{2}{*}{$\begin{array}{c}\text { Exposure } \\
\text { period }\end{array}$} & \multicolumn{3}{|c|}{ Maximum tensile stress (MPa) } & \multicolumn{3}{|c|}{ Modulus of elasticity (MPa) } \\
\hline & Vinyl ester & Epoxy & Ester epoxy & Vinyl ester & Epoxy & Ester epoxy \\
\hline Reference & 39,7 & 41,0 & 34,5 & 2544,7 & 1944,0 & 2024,7 \\
\hline 30 days & 17,1 & 39,8 & 30,7 & 1223,0 & 2438,9 & 2385,3 \\
\hline 90 days & 13,8 & 42,0 & 31,4 & 777,6 & 1547,9 & 1740,1 \\
\hline
\end{tabular}

Some fiber types also suffer from degradation caused by UV radiation. According to ISIS [12], carbon and glass fibers are generally not affected by UV radiation, while aramid fibers undergo slight degradation in the face of UV exposure. Homam and Sheikh [16] studied the isolated effect of exposure to UV rays on FRP composites with epoxy 
resin. In a controlled environment, CFRP and GFRP specimens were exposed to $22^{\circ} \mathrm{C}$ to $38^{\circ} \mathrm{C}$ temperature of, $40 \%$ relative humidity of radiation from UV-A lamps at $156 \mathrm{~W} / \mathrm{m}^{2}$. The specimens were tested for uniaxial tensile and shear using the single-lap bond test. Slight increases in tensile strength and stiffness were observed in the specimens of both composites exposed to UV radiation as compared to those maintained in the laboratory environment for exposure periods of 1200 and 4800 hours. Notably, exposure to UV rays did not significantly affect the shear strength of the composites. The bond between the FRP composite and the concrete substrate was susceptible to degradation due to UV radiation. Kabir et al. [17] studied the concrete/adhesive/FRP bonding in external environments. The authors report the exposure to external environments as the most harmful situation for concrete bond-adhesive-FRP.

\subsection{Climate regions: Köpper-Geiger classification system}

The intensity of weathering effects depends on the climate and microclimate of the place where the structure is allocated. One way to categorize the climate is through the Köppen-Geiger climate classification system, which is used worldwide in different areas (such as climatology, meteorology, geography, bioclimatology, and ecology) and takes into account the average annual and monthly values of temperature and precipitation in addition to climate seasonality. Climatic types are separated by large groups, types, and subtypes. Table 2 presents the nomenclatures and climatic types, while Figure 3 shows the climate classification of Brazil [18].

Figure 3 indicates that tropical climate (Zone A - an average temperature equal to or higher than $18^{\circ} \mathrm{C}$ every month and significant precipitation) is predominant in Brazil, covering $81.4 \%$ of the country's total area. Dry climate (Zone $\mathrm{B}$ - low precipitation throughout the year) is present in some parts of the northeastern states of Brazil, while subtropical climates are dominant in the South and Southeast [18].

According to the Brazilian Agricultural Research Company (EMBRAPA) [19], the city of São Carlos in the state

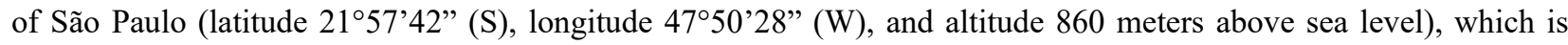
where this research was developed, has a local climate defined as humid subtropical with dry winter and hot summer (known as Cwa). Figure 4 shows other regions of the world that have similar Cfa and Cwa climate types, as per the Köpper-Geiger climate classification system, for which the results obtained in this research can also be expanded.

Table 2 Köpper-Geiger classification system [18]

\begin{tabular}{|c|c|c|}
\hline Group & Type & Subtype (where applicable) \\
\hline \multirow{4}{*}{ A - Tropical } & \multicolumn{2}{|r|}{ f - Equatorial (no dry season, with precipitation $\geq 60 \mathrm{~mm}$ each month) } \\
\hline & \multicolumn{2}{|r|}{ m - Monsonic (with a drier month) } \\
\hline & \multicolumn{2}{|r|}{ w - Savanna with drier season in winter } \\
\hline & \multicolumn{2}{|r|}{ s - Savanna with drier season in summer } \\
\hline \multirow{4}{*}{ B - Dry } & \multirow{2}{*}{$\mathbf{w}$ - Arid } & h -Low latitude and longitude; average annual temperature $\geq 18^{\circ} \mathrm{C}$ \\
\hline & & k - medium latitude and high altitude; average annual temp. $<18^{\circ} \mathrm{C}$ \\
\hline & \multirow{2}{*}{ s - Semiarid } & h -Low latitude and longitude; average annual temperature $\geq 18^{\circ} \mathrm{C}$ \\
\hline & & k - medium latitude and high altitude; average annual temp. $<18^{\circ} \mathrm{C}$ \\
\hline \multirow{9}{*}{ C - Moist Subtropical } & \multirow{3}{*}{$\begin{array}{l}\text { f - Oceanic climate, no dry } \\
\text { season }\end{array}$} & a - Hot summer \\
\hline & & b - Cool summer \\
\hline & & c - Short and cold summer \\
\hline & \multirow{3}{*}{ w - With dry winter } & a - Hot summer \\
\hline & & b - Cool summer \\
\hline & & c - Short and cold summer \\
\hline & \multirow{3}{*}{ s - With dry summer } & a - Hot summer \\
\hline & & b - Cool summer \\
\hline & & c - Short and cold summer \\
\hline \multirow{12}{*}{ D - Temperate Continental } & \multirow{4}{*}{ f - No dry season } & a - Hot summer \\
\hline & & b - Cool summer \\
\hline & & c - Short and cold summer \\
\hline & & d - Very cold winter \\
\hline & \multirow{4}{*}{ w - With dry winter } & a - Hot summer \\
\hline & & b - Cool summer \\
\hline & & c - Short and cold summer \\
\hline & & d - Very cold winter \\
\hline & \multirow{4}{*}{ s - With dry summer } & a - Hot summer \\
\hline & & b - Cool summer \\
\hline & & c - Short and cold summer \\
\hline & & d - Very cold winter \\
\hline \multirow{2}{*}{ E - Polar } & & $\mathbf{T}$ - Tundra (temperature in the hottest month between 10 and $0^{\circ} \mathrm{C}$ ) \\
\hline & & F - Glacial (temperature in the hottest month $<0^{\circ} \mathrm{C}$ ) \\
\hline
\end{tabular}




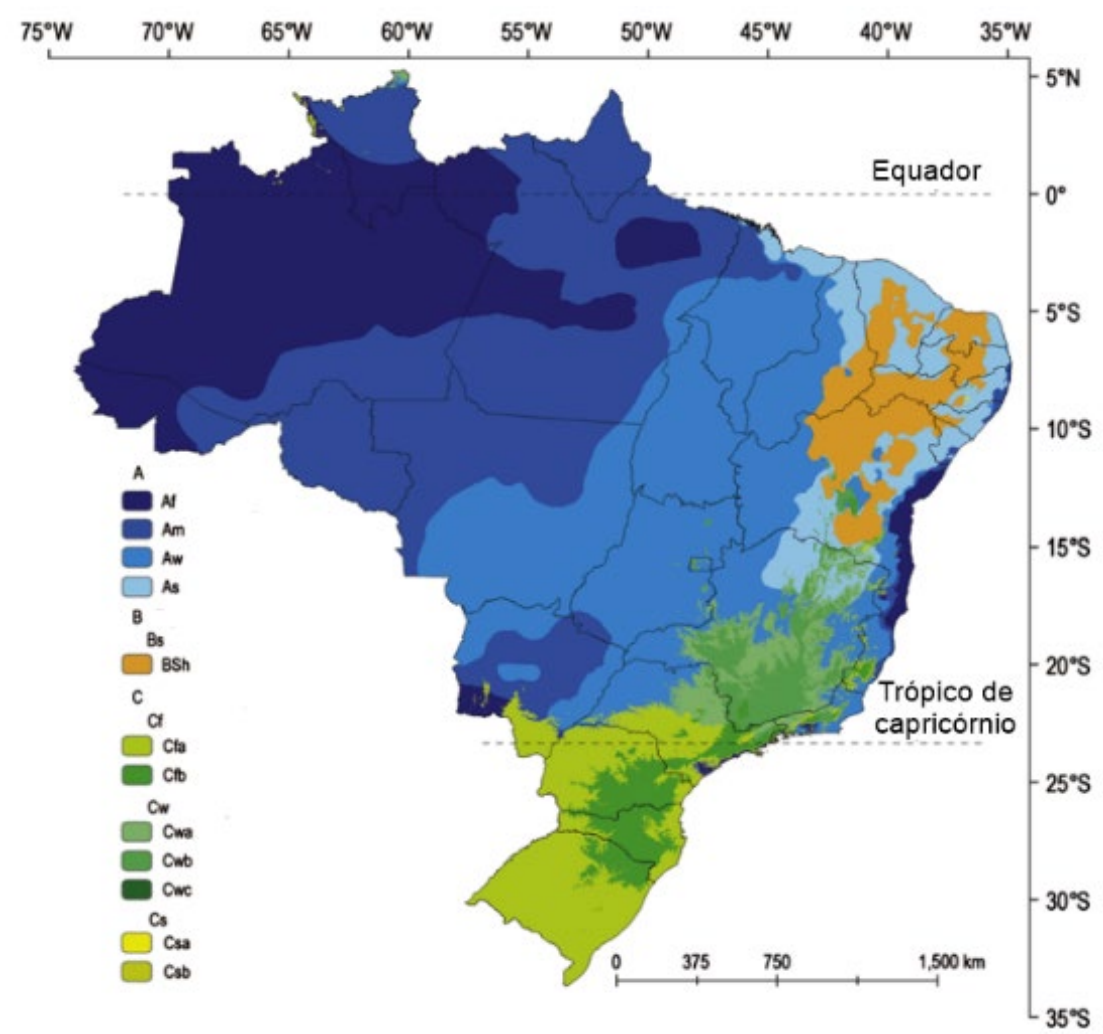

Figure 3. Brazil climate classification in the Köpper-Geiger system [18]

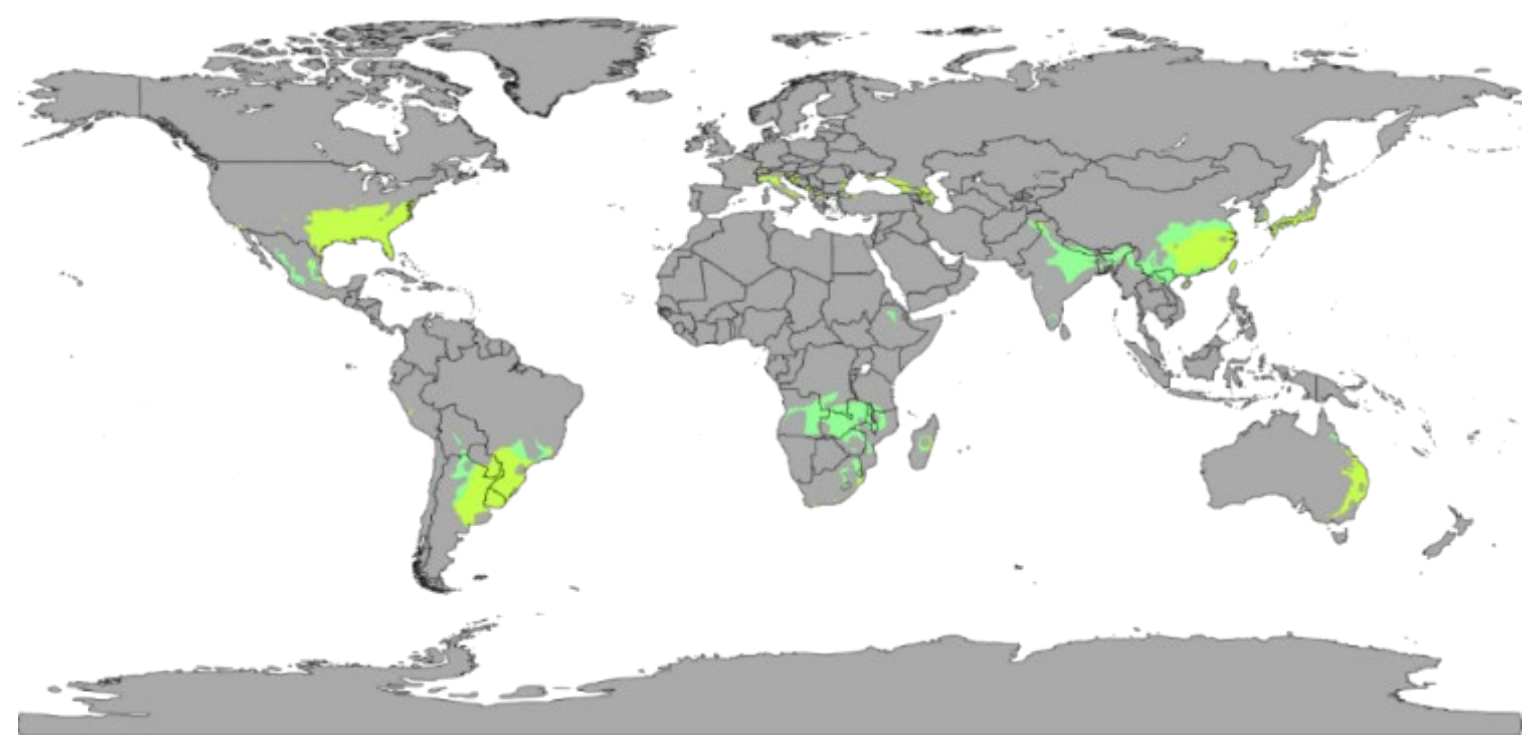

Figure 4. Humid subtropical climate Cfa and Cwa around the world [20]

\section{EXPERIMENTAL PROGRAM}

The research aimed to evaluate the degradation of reinforced concrete beams strengthened with CFRP sheets and exposed to weathering in a humid subtropical climate with dry winter and hot summer (Cwa) in non-accelerated tests. The beams and intervening materials (epoxy resins and CFRP composites) were exposed to two distinct environments: (a) laboratory environment (internal, protected), inside a controlled temperature and humidity chamber for a period of 
6 months (reference), and (b) external environment, wherein the materials were exposed to weathering for the same period of time.

\subsection{Beam geometry, degradation environments, strengthening system, and bending test configuration}

\subsubsection{Beams}

The experimental program consisted on twelve simply supported beams of $120 \times 200 \times 2500 \mathrm{~mm}^{3}, 20-\mathrm{MPa}$, and positive longitudinal reinforcement composed by two CA-50 steel bars (10-mm diameter; reinforcement ratio of 0.75\%). To avoid shear rupture, CA-60 steel stirrups (5-mm diameter and 10-cm spacing) with two top longitudinal reinforcement bars of CA-50 and $6.3 \mathrm{~mm}$ diameter (Figure 5). The beams were designed in the deformation domain 2, based on NBR 6118 [21].
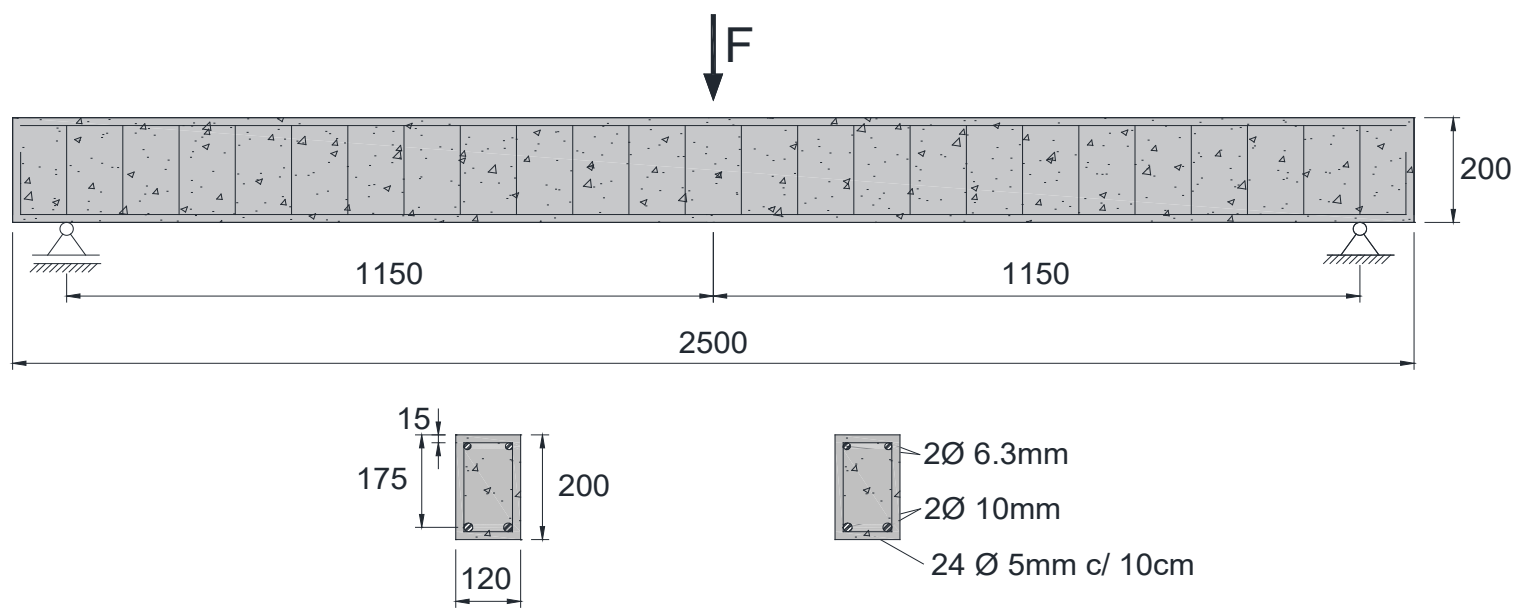

Figure 5. Characteristic of reinforced concrete beams (units in $\mathrm{mm}$ ).

\subsubsection{Strengthening system}

Eight beams were reinforced with unidirectional $300-\mathrm{g} / \mathrm{m}^{2}$ weight carbon fiber sheets of $0.13 \mathrm{~mm}$ thickness. The sheet was cut into $110 \times 2200 \mathrm{~mm}$ strips to fit the tension surface of the reinforced concrete beam (Figure 6).

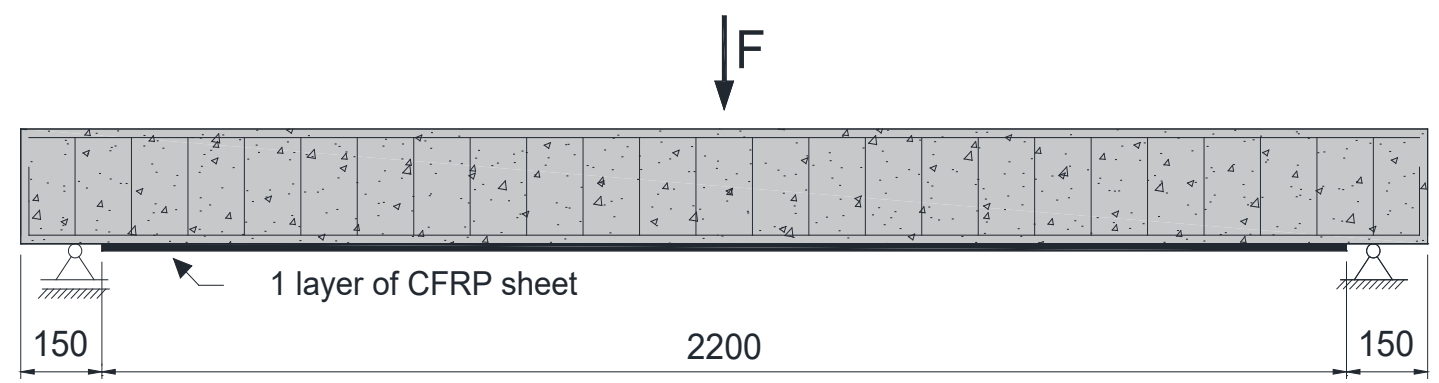

Figure 6. Details of the strengthening system (units in $\mathrm{mm}$ )

The CFRP sheets were applied externally to the beams when they were 186 days old. The substrate was cut with a diamond thinning disc grinder until the entire layer of cement paste was removed and the aggregates were exposed. After, compressed air was applied to the surface for disposing of any solid particles. A layer of the primer resin (Resin A) was applied to improve the adhesion conditions between the CFRP and concrete substrate. The CFRP was bonded using the epoxy lamination resin (Resin B), which was applied 45 minutes after the primer. The primer and saturation resins were 
prepared into three steps: agitation of each component, mixture of component $\mathrm{A}$ to $\mathrm{B}$ in the proportion indicated by the manufacturer, and mechanical mixture until a uniform color was obtained. The primer resin was spread on the concrete surface using a brush. The CFRP sheet was covered with lamination resin and applied to the concrete substrate before the application of the strengthening system. While strengthening, we tried to ensure the alignment of the fibers in the longitudinal direction of the beam, to check the non-formation of air bubbles in the back of the CFRP composite, and to avoid the accumulation of excess resin. The steps and procedures used to strengthen the reinforced concrete beams are depicted in Figure 7.

\subsubsection{Degradation environments}

Of the twelve beams made, four had no strengthening, and the others were strengthened in flexure with one layer of CFRP sheet applied according to the EBR technique. Two exposure environments were adopted in this research (Figure 8), as given below.

- Laboratory environment (LAB): internal to a chamber, protected, and with monitoring of ambient temperature and humidity, which served as a reference for the other tests (Figure 8a)

- Exposure to weathering (WEA): external environment, free of obstacles that promoted shading in beams and specimens, and with monitoring of humidity, temperature, and radiation (Figure 8b).

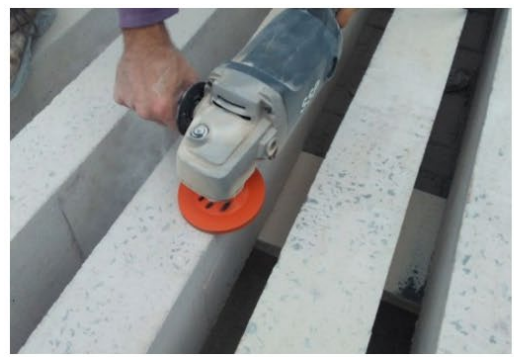

(a)

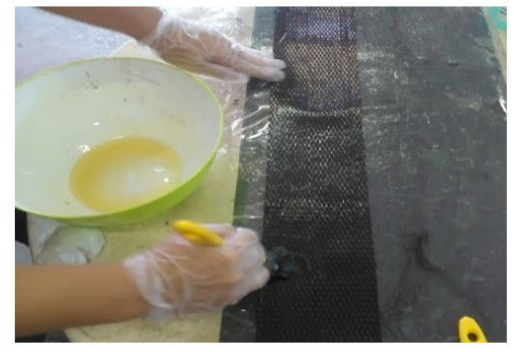

(d)

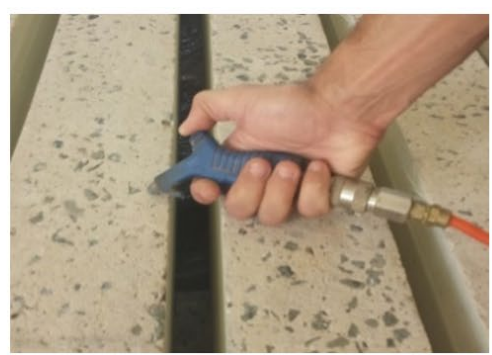

(b)

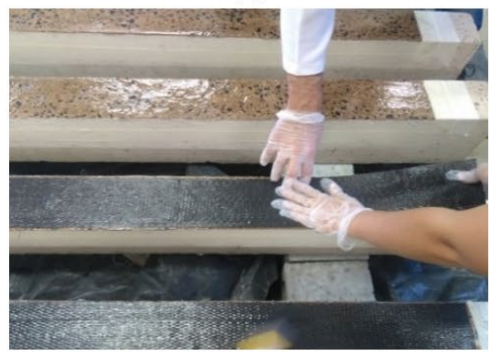

(e)

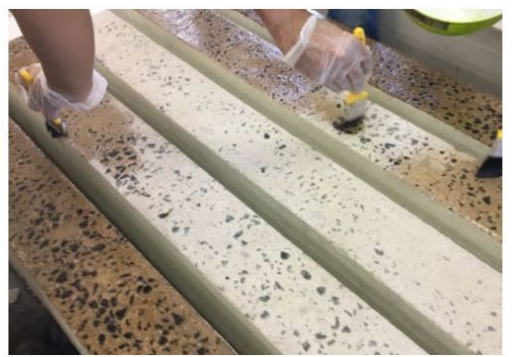

(c)

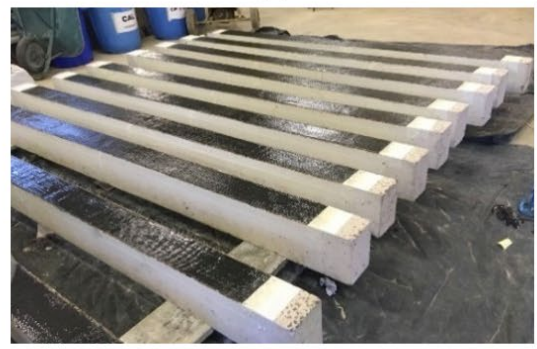

(f)

Figure 7. (a) Preparation of the concrete surface, (b) surface cleaning with compressed air, (c) application of the primer, (d) impregnation of the CFRP composites, (e) application of CFRP to the concrete substrate and (f) final aspect of the strengthened members

Each beam was identified as Vx_y_z, where "x" is the number of tested elements, " $y$ " corresponds to the elements used as reference (REF, of Reference), maintained in a laboratory environment (LAB, of laboratory), or exposed to weathering (WEA, of Weathering), and " $\mathrm{z}$ " due to the use or not of strengthening material (0 or 1 layer of CFRP sheet). The strengthening system was also analyzed, specifically the epoxy resins and the CFRP composites. Table 3 presents a summary of the experimental program wherein Vx_REF_0 and Vx_REF_CFRP refer to the beams without and with strengthening, respectively, maintained in the same environment and tested on the same date -200 days after concreting - which were considered as references for the other analyses. The Vx_LAB_CFRP and Vx_WEA_CFRP refer to the beams strengthened with CFRP and maintained in laboratory chamber environment or exposed to weathering, tested 6 months after the application of the strengthening. The other beams will be tested 2 years after strengthening and exposure to the environments previously mentioned. 


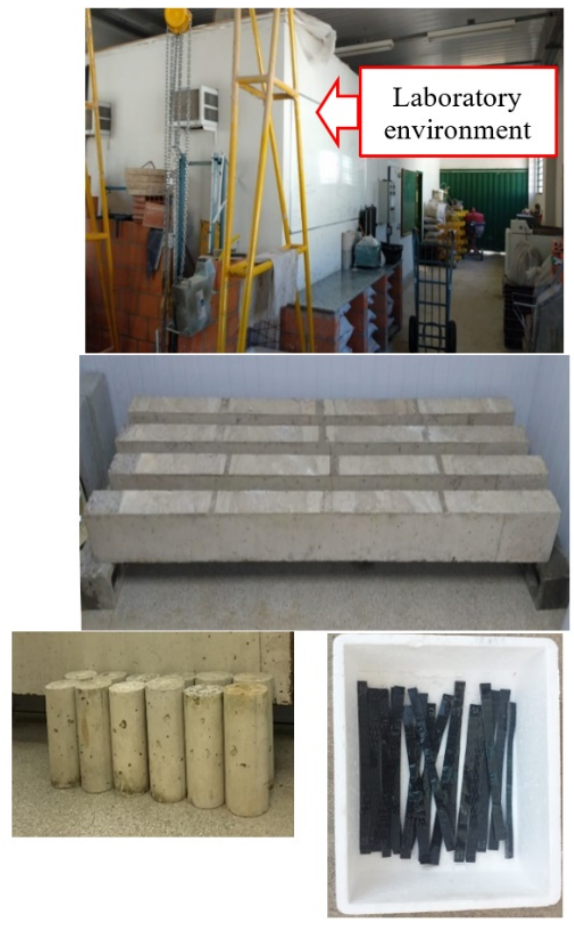

(a)

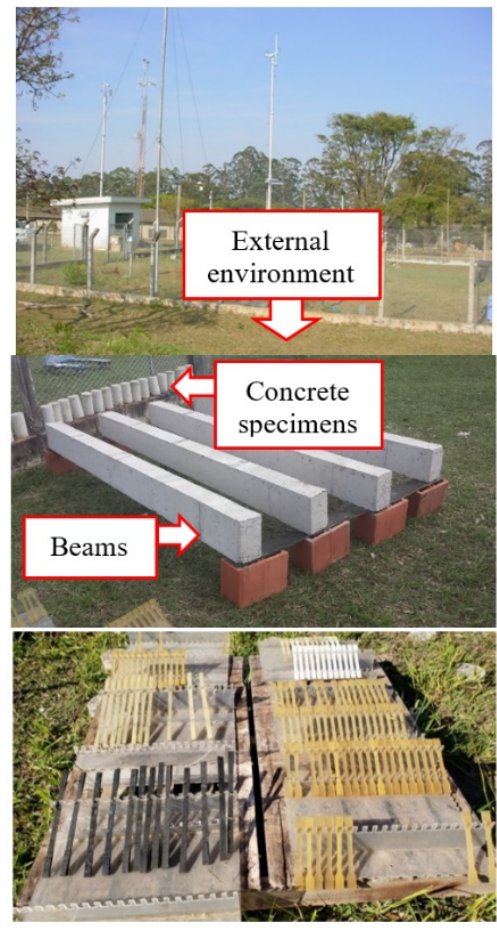

(b)

Figure 8. Exposure environments: (a) isolated and protected chamber and (b) exposure to weather (outdoor environment)

Table 3 Test program for reinforced concrete beams

\begin{tabular}{|c|c|c|c|c|c|}
\hline Group identification & Strengthening & Environment & Identification of beams & Condition for performing the test & $\begin{array}{c}\begin{array}{c}\text { Number of } \\
\text { beams }\end{array} \\
\end{array}$ \\
\hline \multirow{2}{*}{ V_REF_0 } & \multirow{2}{*}{ No strengthening } & \multirow[b]{2}{*}{$\mathrm{LAB}$} & V1_REF_0 & \multirow[b]{2}{*}{ Test conducted at the age of 200 days } & \multirow[b]{2}{*}{2} \\
\hline & & & V2_REF_0 & & \\
\hline \multirow[b]{2}{*}{ V_REF_CFRP } & \multirow[b]{2}{*}{ CFRP } & \multirow[b]{2}{*}{ LAB } & V1_REF_CFRP & Strengthening performed at the age of 186 days & \multirow[b]{2}{*}{2} \\
\hline & & & V2_REF_CFRP & $\begin{array}{l}\text { Test performed at the age of } 200 \text { days ( } 14 \text { days } \\
\text { after application of the strengthening system, time } \\
\text { considered to be the complete cure of epoxy } \\
\text { resin) }\end{array}$ & \\
\hline \multirow[b]{2}{*}{ V_LAB_CFRP } & \multirow[b]{2}{*}{ CFRP } & \multirow[b]{2}{*}{ LAB } & V1_LAB_CFRP & \multirow[b]{2}{*}{ Strengthening carried out at the age of 200 days } & \multirow[b]{2}{*}{2} \\
\hline & & & V2_LAB_CFRP & & \\
\hline \multirow[t]{2}{*}{ V_WEA_CFRP } & \multirow[t]{2}{*}{ CFRP } & \multirow[t]{2}{*}{ WEA } & V1_WEA_CFRP & \multirow{2}{*}{$\begin{array}{l}\text { Test performed } 380 \text { days after concreting } \\
\text { (6 months after the application of the } \\
\text { strengthening system) }\end{array}$} & \multirow[t]{2}{*}{2} \\
\hline & & & V2_WEA_CFRP & & \\
\hline
\end{tabular}

\subsubsection{Test configuration}

The three points bending tests were performed with midspan point load, using a universal EMIC testing machine (model DL 60000 available at the Structural Systems Laboratory [LSE] of the Federal University of São Carlos [UFSCar]).

A self-reaction system was designed to allow testing the beam inside the universal testing machine. A double corbel element (Figure 9a) was designed using 31.75-mm and 25.40-mm thick. The corbel was fixed to the testing machine base and supported a $250-\mathrm{cm}$ long steel section (W200 x 26.6). The corbel was screwed to the base of the test machine using six steel hexagon screws type M12, and the metal profile was mounted on it with eight steel hexagon screws type M10. The concrete beams were supported on the metal profile at a roller and at a fixed support, as shown in Figure 9b. 
To measure the rotation of the supports and displacement of the steel beam ends, two Linear Variable Differential Transformers (LVDTs) with 25-mm stroke and two potentiometers with 20-mm stroke were used, positioned as shown in Figure 9b, 9c.

(a)
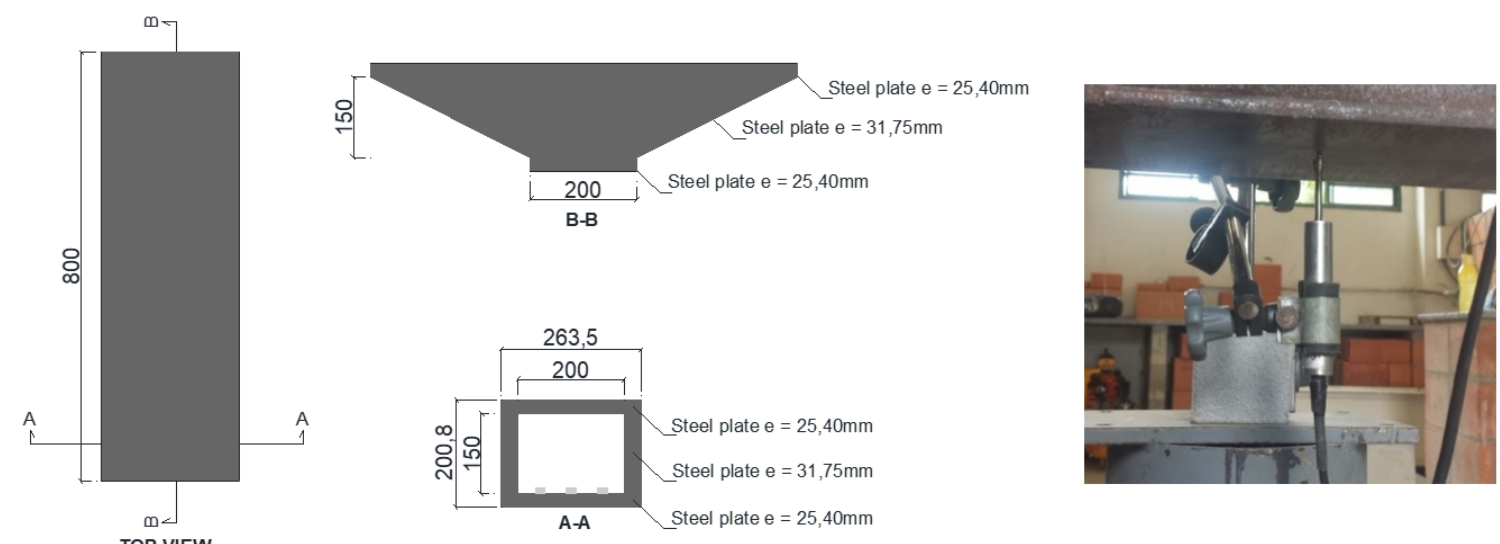

(b)

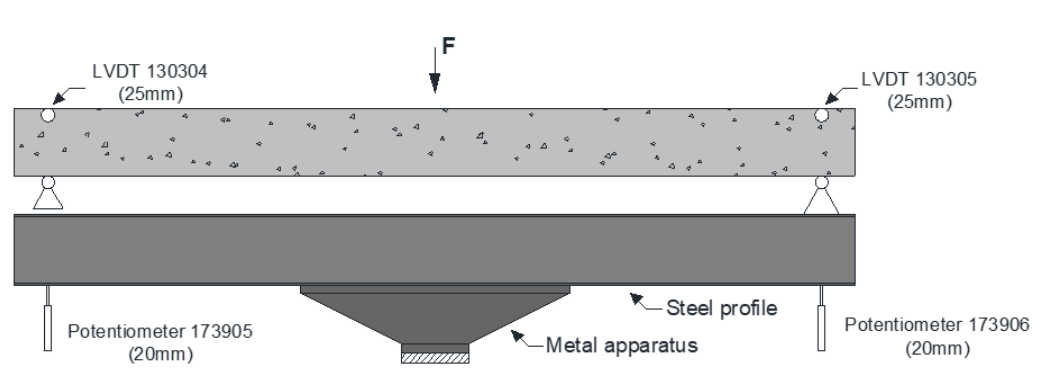

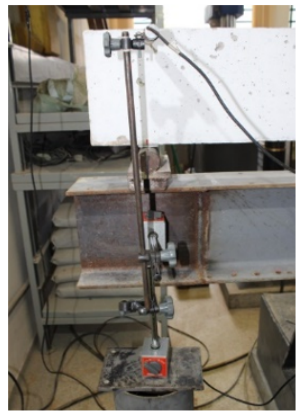

(c)

Figure 9. (a-b) Steel apparatus and (c) details of the positioning of the LVDTs and potentiometers used to measure the displacement of the metal beam and rotation of the supports (units in Figure 9a: $\mathrm{mm}$ )

The loading was applied at $0.50 \mathrm{~mm} / \mathrm{min}$ displacement. The load application was double recorded using an external 200-kN load cell (with reading resolution of $0.01 \mathrm{kN}$ ), in addition to the test machine load cell, which had a load cell with a maximum capacity of $600 \mathrm{kN}$ and reading resolution of $0.1 \mathrm{kN}$. The displacements and deformations in concrete, longitudinal reinforcement and CFRP composite were recorded using an ADS-2000 model data acquisition system (manufactured by LYNX). Beam instrumentation included a displacement transducer and six electrical strain gauges. A Vishay displacement transducer, with a linear range of $50 \mathrm{~mm}$, was used to measure the vertical displacement of the beams. This was fixed to an external support and positioned at the midspan at the beams.

The deformations in the concrete were measured on an electric strain gauge of type PA-06-1500BA-120 (resistance of $120 \Omega$ and length of the reading grid of $40 \mathrm{~mm}$; produced by Excel Sensors), which was positioned in the middle of the beams (SG1). The deformations in the longitudinal strengthening were measured on electrical strainers of type KFG-20-120-C1-11 (resistance of $120 \Omega$ and length of the reading grid of $20 \mathrm{~mm}$; produced by KYOWA), which was positioned in the section of the central section of one of the longitudinal strengthening (SG2). In relation to CFRP composite deformations, electrical strain gages of type KFG-20-120-C1-11 (the same used in longitudinal strengthening) and type PA-06-250BA-120 (resistance of $120 \Omega$ and reading grid length of $6 \mathrm{~mm}$; produced by Excel Sensors), positioned along the strengthening material (SG3 to SG5). Figure 10 shows the instrumentation used.

\subsubsection{Characterization of materials}

Characterizing the concrete included an analysis of the axial compressive strength and modulus of elasticity. Molding and curing procedures were performed, as prescribed by NBR 5738 [22], and cylindrical specimens $200 \mathrm{~mm}$ 
in height and $100 \mathrm{~mm}$ in diameter were molded. 24 hours after the casting, the specimens were demolded and positioned in the same environment as the beams.

The CFRP composite manufacturing system, which supplies the fiber and matrix separately, is known as the "in situ" cured system. In this experiment, an in situ cured system was used.

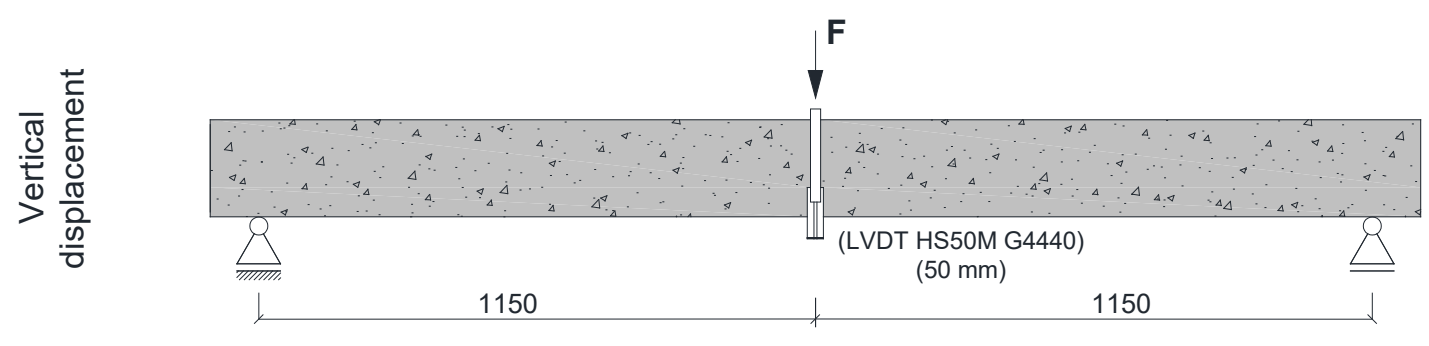

0
$\frac{0}{0}$
0
0
0
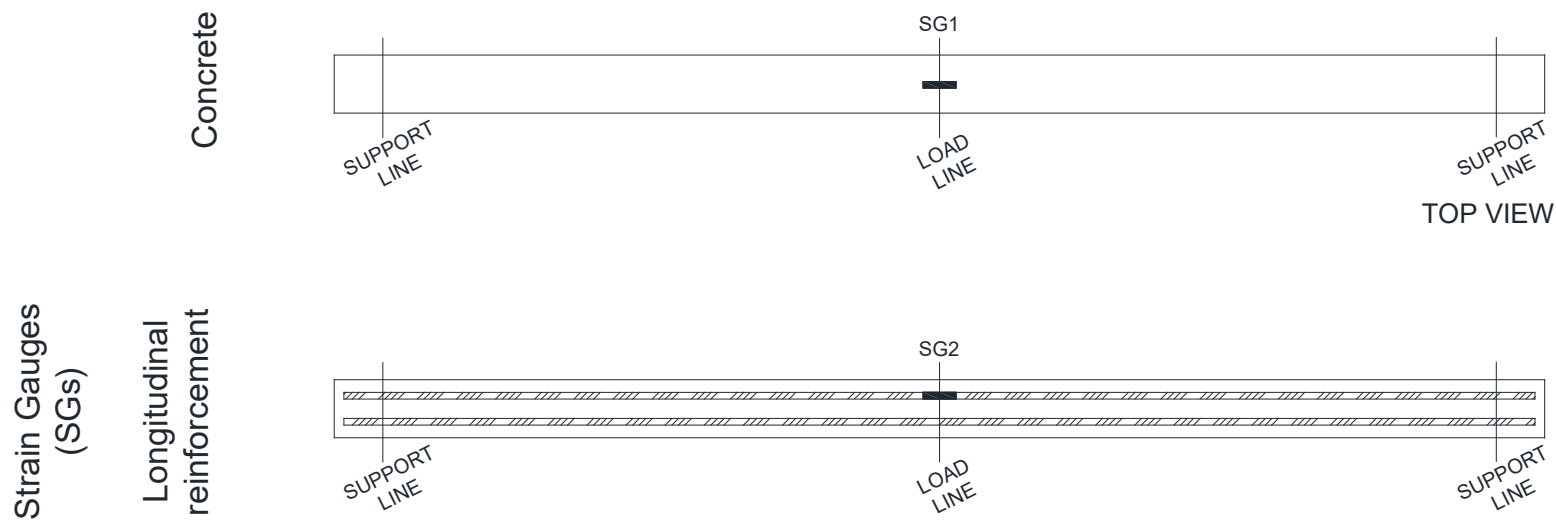

VIEW OF THE BOTTOM REINFORCEMENT

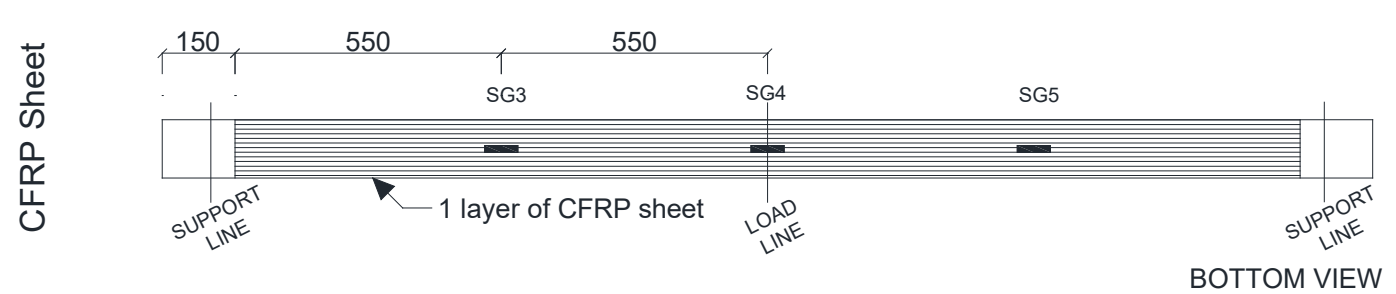

Figure 10. Instrumentation used in beam testing (units in $\mathrm{mm}$ )

A layer of unidirectional carbon fiber mat weighing $300 \mathrm{~g} / \mathrm{m}^{2}$ was impregnated with epoxy resin. The carbon fiber sheet had to have at least tensile strength of $3800 \mathrm{MPa}$, modulus of elasticity of $240 \mathrm{GPa}$, and deformation at rupture of $15.5 \%$. More information on the characterization of the CFRP composites and experimental results can be found in Ferreira [23].

The adhesives used to fix the composite strengthening system to the concrete substrate were supplied by the same manufacturer of the carbon fiber sheet used in this work. In the experiment, bi-component epoxy primer and lamination resins were used. The characterization tests of epoxy resins and CFRP composites were carried out at the Polymer Laboratory of the Materials Engineering Department (DEMa) of UFSCar. More information on the characterization of adhesives and the experiment results can also be found in Ferreira [23].

The mechanical properties of the steel were evaluated by axial tensile tests, according to the recommendations of NBR 6892-1 [24]. A minimum of three specimens, $50 \mathrm{~cm}$ in length and randomly chosen, were tested for each bar diameter used. Both steel and concrete characterization tests were performed at LSE. 


\section{RESULTS AND DISCUSSION}

This section presents the results of the tests of characterization of the materials and the behavior of concrete beams without strengthening and reinforced with a layer of CFRP sheet.

\subsection{Environmental data}

The temperature and average humidity readings in the laboratory environment were $23.3^{\circ} \mathrm{C}( \pm 0.03 \%)$ and $36.5 \%$ $( \pm 0.24 \%)$, respectively. The values in parentheses represent the Coefficient of Variation (COV). For exposure to weathering (external environment), Figure 11 presents the data of temperature, humidity, and UV radiation throughout the exposure period of the beams and concrete specimens, i.e., from May to November 2018. During this period the maximum and minimum temperatures were $34.2^{\circ} \mathrm{C}$ and $4.7^{\circ} \mathrm{C}$, and the maximum and minimum humidity were $95 \%$ and $16 \%$, respectively. Regarding UV radiation, the surface weather station recorded a peak of $4112 \mathrm{~kJ} / \mathrm{m}^{2}$ and an average of $788 \mathrm{~kJ} / \mathrm{m}^{2}$ over the exposure period.

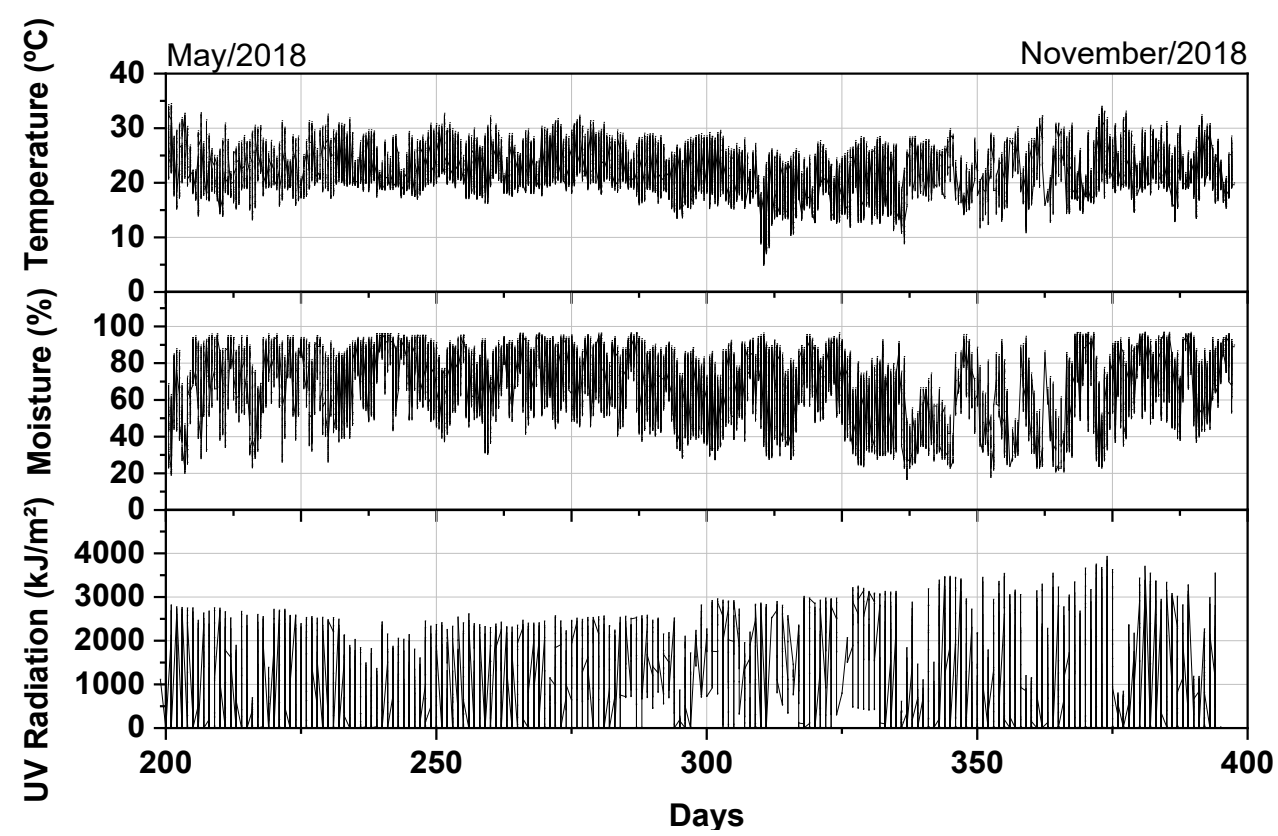

Figure 11. Weather data for the weather exposure. Source: INMET

\subsection{Mechanical properties}

\subsubsection{Concrete}

Concrete properties were tested 28 days after concreting and also on the day of the beam tests, which were performed at the age of 200 days (REF) and 380 days (LAB and WEA). The results showed the mean values of compressive strength of $22.0 \mathrm{MPa}( \pm 3.50 \%)$ and $28.5 \mathrm{MPa}( \pm 0.54 \%)$ and modulus of elasticity of $29.3 \mathrm{GPa}( \pm 7.03 \%)$ and $31.6 \mathrm{GPa}$ $( \pm 5.32 \%)$ obtained at 28 and 200 days, respectively. For the specimens that were kept in the laboratory environment (LAB) or exposed to weathering (WEA), mean values of $27.4 \mathrm{MPa}( \pm 0.50 \%)$ and $25,2 \mathrm{MPa}( \pm 6.94 \%)$ for compressive strength and $31.2 \mathrm{GPa}( \pm 2.87 \%)$ and $28.5 \mathrm{GPa}( \pm 3.06 \%)$ for modulus of elasticity, respectively, were obtained in the test performed at the age of 380 days.

\subsubsection{Steel}

Regarding the characterization of steel, for bars with a diameter of $5 \mathrm{~mm}$, type CA-60, an average yielding stress was observed at $2.0 \%$ of $646.9( \pm 4.04 \%) \mathrm{MPa}$ and a maximum tensile stress of $670.6( \pm 3.62 \%)$ MPa (Figure 12a). For steel with a diameter of $10 \mathrm{~mm}$, a typical behavior of CA-50 steel was verified with a plastic plateau (Figure 12b), 
with an average yielding stress of $547.4 \mathrm{MPa}( \pm 2.13 \%)$, mean yielding strain of $2.8 \%$ o $( \pm 1.59 \%)$, and a maximum tensile stress of $591.5 \mathrm{MPa}( \pm 6.25)$. The elasticity modules verified for the $10 \mathrm{~mm}$ and $5 \mathrm{~mm}$ bars were $196.9 \mathrm{GPa}$ $( \pm 1.58 \%)$ and $191.3 \mathrm{GPa}( \pm 7.19 \%)$, respectively.

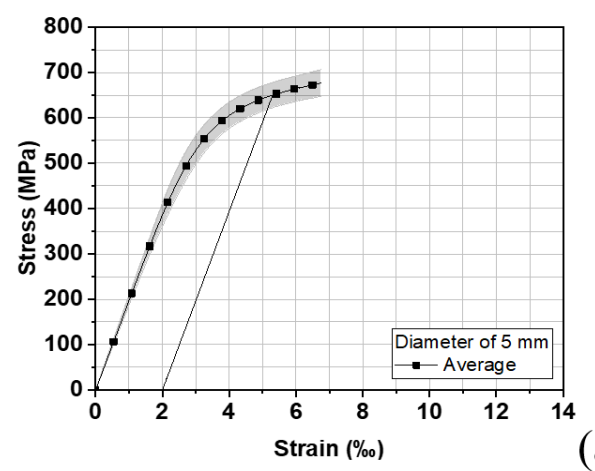

(a)

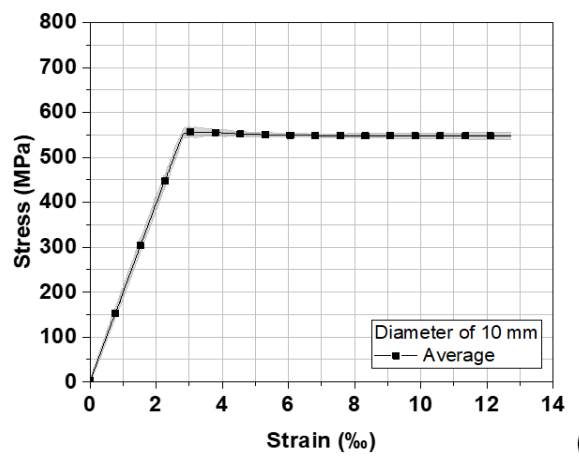

(b)

Figure 12. Stress versus deformation of materials: (a) stirrups and (b) steel of longitudinal reinforcement

\subsubsection{Epoxy resins}

The characterization tests for the resins were experimentally performed at the ages of 7 and 14 days and 4 and 8 months after the application of the strengthening system, as presented in Figure 13. Considering 14 days of cure for Resin A (Figure 13a), which was maintained in a laboratory environment, the material presented a small increase in maximum tension and modulus of elasticity $(5.7 \%$ and $4.5 \%$, respectively) at 4 months. After 8 months of exposure and with the results of the tests performed at 14 days as a reference, there was no major change in the maximum tensile stress of the primer, which presented a small reduction of $2.9 \%$. However, a $9.1 \%$ reduction in the modulus of elasticity was verified in the assays. There was also a small reduction in the ductility of the specimens after 8 months of exposure in a laboratory setting. Therefore, there were no significant changes in the mode of rupture and stress-strain behavior throughout the exposure period in the laboratory environment.

Considering the exposure to weather of Resin A (Figure 13b) and with the tests performed at 14 days as a reference, a reduction of $39.1 \%$ in tensile strength and $4.5 \%$ in the modulus of elasticity was noted at 4 months. At 8 months of exposure, a sharper reduction in tensile strength (about $51.0 \%$ ), while the modulus of elasticity showed a reduction of $9.1 \%$. It was also verified, for both ages, that the reduction of ductility of the specimens with alteration in the mode of rupture from ductile to fragile without a defined plasticization interval. Further, Resin B, which was maintained in a laboratory environment (Figure 13c) did not present major changes in its mechanical properties (reduction of only about $3.1 \%$ of tensile strength) up to 4 months of exposure. However, after 8 months, there was a considerable reduction of $23.8 \%$ and $19.2 \%$ in tensile strength and modulus of elasticity, respectively. This reduction in tensile strength and modulus of elasticity did not alter the behavior of the stress-strain diagram, and the maximum stress level continued to be reached with close deformations. At 7 days of cure, the tensile strength was already close to that obtained in the complete cure indicated by the manufacturer (14 days). For Resin B's exposure to weather (Figure 13d), the stress-strain diagrams did not present major changes at 7 and 14 days, only a small increase in the maximum tension. After 4 months, there were remarkable losses in its mechanical properties, with a reduction in its tensile strength and modulus of elasticity of $63.3 \%$ and $9.1 \%$, respectively. At 8 months, the maximum tensile strength decreased sharply (about $69.2 \%$ ), while the modulus of elasticity showed a reduction of $18.2 \%$. Observed, also, the reduction of ductility for both ages of exposure with alteration in the mode of rupture, which occurs abruptly and without any stretch of plasticization. Unlike Resin A, Resin B yielded a considerable loss in its mechanical properties after 8 months of exposure to the laboratory environment. Another divergence found in the epoxy resins is related to their mechanical properties at 14 days of curing. It was noted that both the tensile strength and modulus of elasticity of Resin B were higher (about 16\%) than those of Resin A despite the equivalent curing time. 
Laboratory environment
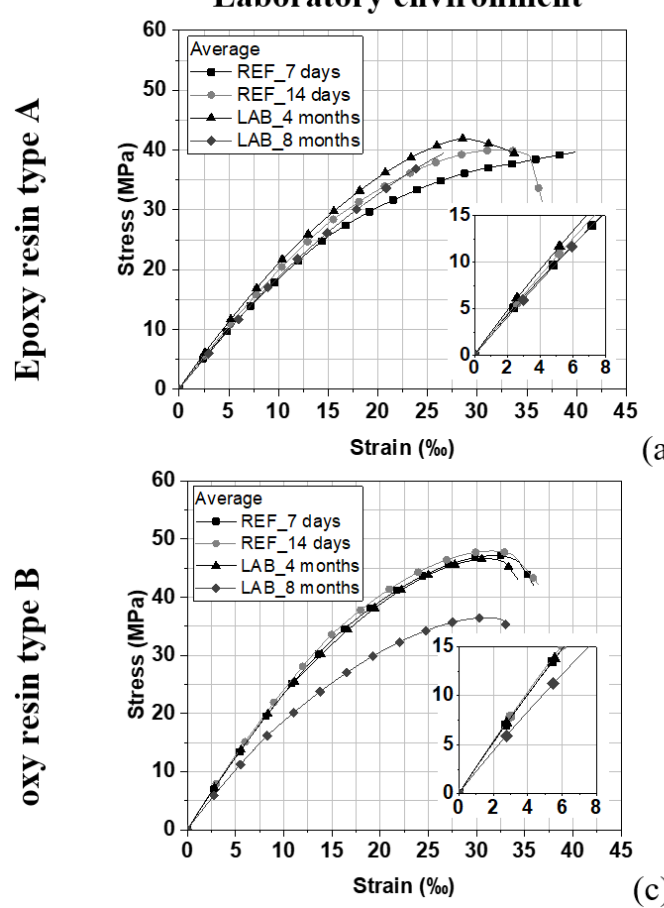

(a)

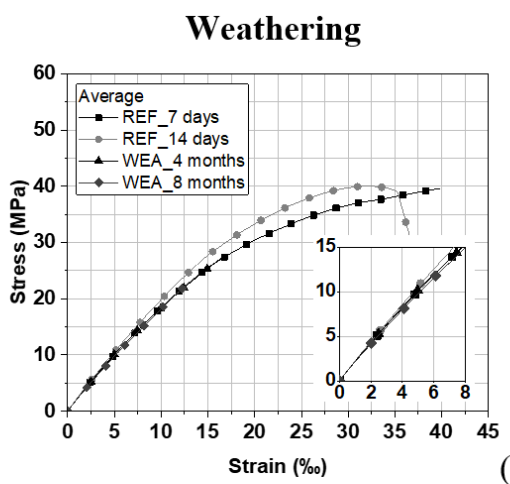

(b)

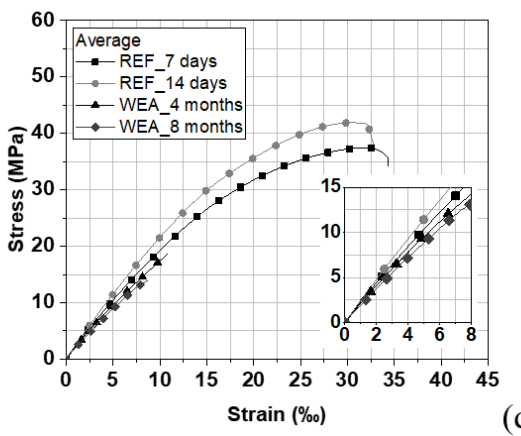

(d)

Figure 13. Stress versus strain relationship of primer (a-b) and saturation (c-d) resins maintained in a laboratory environment or exposed to weathering

In a study carried out by Fernandes et al. [25], epoxy resins were also kept in a laboratory environment for a period of 2 years. The results, as in the present study, also showed small reductions in their mechanical properties, specifically $5.5 \%$ and $6.9 \%$ in tensile strength and modulus of elasticity, respectively. The findings for the epoxy saturation resins (Resin B) exposed to weather were also verified in a research conducted by Escobal [26]. The author evaluated the degradation of epoxy saturation resins exposed to weather (external environment with monitored temperature and humidity) for a total period of 4 months. The results showed losses of $44 \%$ in tensile strength after 4 months of exposure. Escobal [26] also evaluated the same epoxy resins exposed to accelerated aging cycles, contained by UV radiation, temperature of $60^{\circ} \mathrm{C}$, and water vapor at $50^{\circ} \mathrm{C}$. The results showed a considerable reduction in the tensile strength of the resins (about 60\%), as verified in the present work for resins A and B exposed to the weather. The results found by Zhao et al. [15] were also similar to those in this study. The authors evaluated epoxy resin specimens exposed to UV radiation cycles (simulating exposure in an external environment) for a period of 90 days. At the end of the trials, the authors verified a maximum reduction of $20.4 \%$ in the modulus of elasticity of the specimens.

\subsubsection{CFRP composites}

For CFRP composites (Figures 14a, 14b), the specimens presented a linear elastic behavior until their rupture, typical of fragile materials. Regarding their exposure to the laboratory environment (Figure 14a), a more significant variation was seen in the behavior of the specimens after the ages of 4 and 8 months. Further, a greater reduction in the tensile strength of the specimens occurred after 4 months of exposure (reduction of about $15 \%$ of tensile strength). During this same period, there was a small reduction of $1.73 \%$ in the modulus of elasticity. After 8 months of exposure, the CFRP composite specimens gained resistance and showed a lower loss in tensile strength, at about $11 \%$, while the modulus of elasticity reduced by only $3.3 \%$. The last deformation also showed reductions of $14 \%$ and $7 \%$ over 4 and 8 months' exposure to the laboratory environment, respectively. It was verified that a greater loss occurred in the test performed at 4 months.

For weather exposure (Figure 14b), and taking as reference the tests performed at 14 days, a reduction in tensile strength, modulus of elasticity, and last deformation of $18 \%, 4.9 \%$, and $13.3 \%$, respectively, after 4 months of exposure was verified. At the age of 8 months, the specimens of the CFRP composite presented reductions of $1.4 \%, 1.3 \%$, and $0.7 \%$ in tensile strength, modulus of elasticity, and last deformation, respectively. Once again, there was a significant 
variation in the behavior of the samples for the analyzed ages. Although the properties of CFRP composites present reductions over exposure time, these oscillations do not mean that the material has degraded. Therefore, it is important to verify the coefficient of variation in the properties of the samples, which, as mentioned before, present considerable variation.

Cromwell et al. [27] also found that the exposure of CFRP laminates to aggressive environments, such as constant humidity and saline solution, does not cause major changes in their tensile strength and modulus of elasticity or ultimate deformation.

In another research by Dalfré [28], there was no significant change in tensile strength and modulus of elasticity of CFRP composite specimens exposed to cycles of constant humidity and humidity for a total period of 2 years.
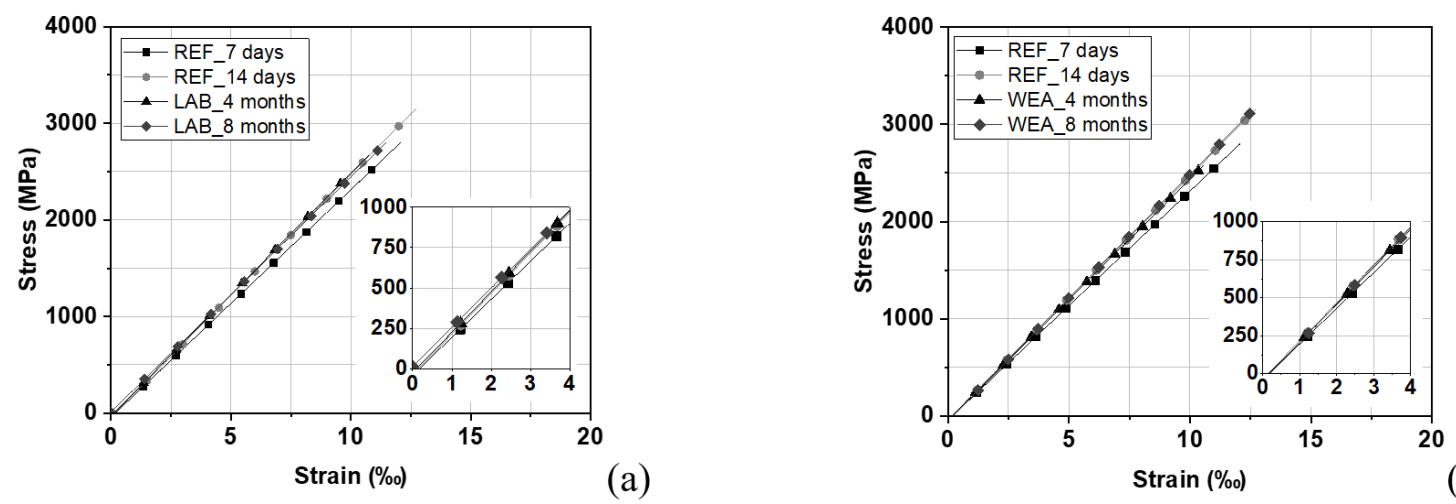

Figure 14. Stress versus strain relationship of CFRP composites maintained in laboratory environment (a) or exposed to weathering (b)

\subsection{Concrete beams behavior}

The behavior of the reinforced concrete beams (with and without strengthening) exposed to the laboratory environment and weathering was analyzed based on ductility, increased load capacity, deformation of materials (concrete, steel, and CFRP), and rupture mode of the strengthening system.

The stop criterion adopted for the reference beams tests without strengthening was established in terms of the deformation of the bending strengthening (at the time the deformation in the steel reached the average value of $11 \%$ ), while that adopted in the reinforced beams of reference and exposed in laboratory environment and weather was established in terms of the failure of the strengthening system, followed by a sudden loss of load and detachment of the material.

Table 4 presents a summary of the average results obtained in the tests of the beam sets for the yielding of the steel reinforcement $\left(\varepsilon_{s y}\right)$, for the concrete crushing $\left(\varepsilon_{c, e s m}\right)$, and the instant that the beams reach maximum loading $\left(F_{\max }\right)$. The indicator of effectiveness of the bending strengthening system in terms of increased load capacity (IR) is also presented, which was obtained by analyzing the average load $\left(F=\left(F_{V 1}+F_{V 2}\right) / 2\right)$ recorded for the beams without strengthening and strengthened (reference and exposed to the environments), respectively.

Table 4 Resume of the average experimental results

\begin{tabular}{|c|c|c|c|c|c|c|c|c|c|c|c|c|c|c|c|c|}
\hline \multirow{2}{*}{$\begin{array}{l}\text { Group of } \\
\text { beams }\end{array}$} & \multicolumn{5}{|c|}{$\begin{array}{l}\text { Yielding of the steel reinforcement } \\
\qquad\left(\varepsilon_{s y}\right)\end{array}$} & \multicolumn{5}{|c|}{$\begin{array}{l}\text { Concrete crushing } \\
\qquad\left(\varepsilon_{c, e s m}\right)\end{array}$} & \multicolumn{6}{|c|}{ Maximum force recorded } \\
\hline & $\begin{array}{l}F_{s y} \\
\mathbf{k N}\end{array}$ & $\begin{array}{c}u_{s y} \\
\mathbf{m m}\end{array}$ & $\begin{array}{l}\varepsilon_{c} \\
\% \text { \% }\end{array}$ & $\begin{array}{c}\varepsilon_{f, \max } \\
\mathbf{\% o}\end{array}$ & $\begin{array}{l}\text { IR } \\
\%\end{array}$ & $\begin{array}{c}F_{c, e s m} \\
\mathbf{k N}\end{array}$ & $\begin{array}{l}u_{e s m} \\
\mathbf{m m}\end{array}$ & $\begin{array}{l}\varepsilon_{s y} \\
\mathbf{\% o}\end{array}$ & $\begin{array}{c}\mathcal{E}_{f, \max } \\
\mathbf{\% o}\end{array}$ & $\begin{array}{l}\text { IR } \\
\%\end{array}$ & $\begin{array}{r}F_{\max } \\
\mathbf{k N}\end{array}$ & $\begin{array}{c}u_{F \max } \\
\mathbf{m m}\end{array}$ & $\begin{array}{c}\varepsilon_{c} \\
\%\end{array}$ & $\begin{array}{l}\varepsilon_{s} \\
\% \text { \% }\end{array}$ & $\begin{array}{c}\varepsilon_{f, \max } \\
\% \text { \%o }\end{array}$ & $\begin{array}{l}\text { IR } \\
\%\end{array}$ \\
\hline REF_0 & 21.8 & 10.3 & 1.8 & ---- & --- & 25.4 & 15.6 & 5.2 & ---- & ---- & 27.0 & 25.2 & 6.1 & 11.4 & ---- & --- \\
\hline REF_CFRP & 26.1 & 9.3 & 1.8 & 2.9 & 19.7 & 31.5 & 13.3 & 5.5 & --- & 24.0 & 40.6 & 32.7 & 9.8 & 13.5 & 9.9 & 50.0 \\
\hline LAB_CFRP & 22.8 & 8.6 & 1.2 & 3.1 & 4.6 & 25.4 & 16.0 & 8.3 & --- & 0.0 & 38.0 & 39.9 & 3.2 & 17.4 & ---- & 40.7 \\
\hline WEA CFRP & 23.9 & 9.0 & $*$ & 2.9 & 9.6 & --- & ---- & --- & ---- & ---- & 36.5 & 32.5 & ---- & 11.6 & --- & 35.1 \\
\hline
\end{tabular}

*Mechanically damaged strain gauge 
In order to evaluate the effectiveness of the strengthening system with CFRP sheets applied according to the EBR technique, Figure 15 presents a comparison between the Load and vertical displacement of the reference beams without strengthening (V1_REF_0 and V2_REF_0) and strengthened (V1_REF_CFRP and V2 REF_CFRP). Upon analysis of Table 4 and Figure 15 , it is possible to verify the effectiveness of the CFRP EBR strengthening system for the reinforced beams without strengthening and the increase in the load capacity of the strengthened beams.

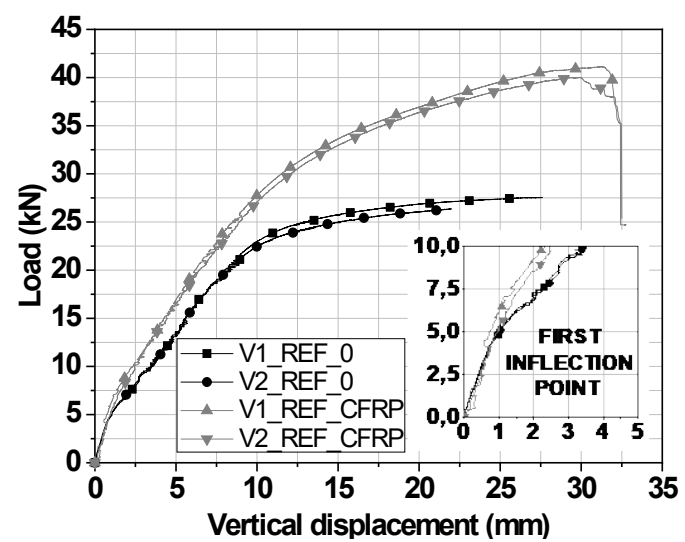

Figure 15. Load versus displacement of reference beams without strengthening and strengthened

In relation to the beginning of the steel yield, it was verified that the strengthening provided an increase in the load capacity corresponding to the beginning of the longitudinal steel yielding and the maximum force of $19.7 \%$ and $50 \%$, respectively. In addition, a reduction in the average vertical displacement of $9.7 \%$ for the strengthened reference beams, compared to the reference beams without strengthening due to the reduction of cracking that the strengthening system promotes, restricting the reduction of element inertia was observed.

As failure modes, the reference beams without strengthening, V1_REF_0 and V2_REF_0, designed in Domain 2, presented a ductile rupture characterized by the yielding of the longitudinal tensile reinforcement and later crushing of the compressed concrete. All the strengthened beams (V1_y_CFRP and V2_y_CFRP), after great deformation and high curvature of the elements, showed appearances of cracks parallel to the strengthening material in the moments before the failure of the element. Therefore, it appears that the use of the CFRP EBR strengthening system alters the failure mode of the strengthened elements. The failure, which was previously ductile and ruled by the deformation of the longitudinal strengthening, became almost fragile with the detachment of the CFRP sheet adhered to the concrete substrate. Figure 16 presents a comparison between Load and vertical displacement relationship of the reference beams without strengthening (V1_REF_0 and V2_REF_0) and strengthened (V1_REF_CFRP and V2_REF_CFRP), with those exposed in laboratory environment (V1_LAB_CFRP and V2_LAB_CFRP) and to weathering (V1_WEA_CFRP and V2_WEA_CFRP), respectively.

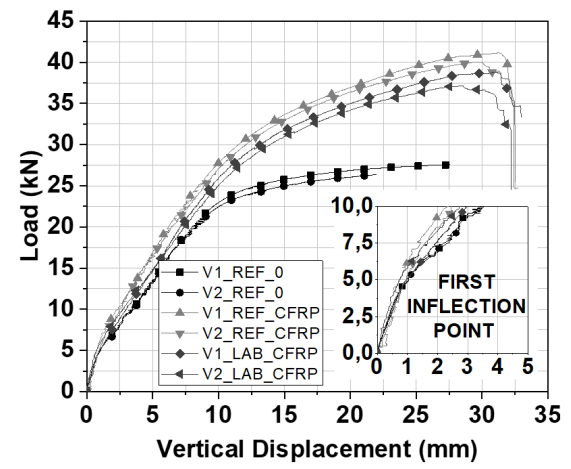

(a)

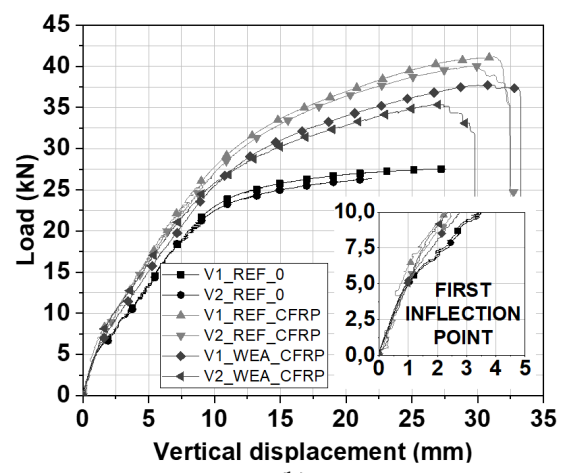

(b)

Figure 16. Relationship between Load versus vertical displacement of reference beams exposed to the environments: (a) laboratory and (b) weathering 
For the yielding of the steel reinforcement of the strengthened beams maintained in laboratory environment or exposed to weathering, an average increase in load capacity of 4.6 and $9.6 \%$, respectively, was observed in relation to the yielding of the steel in the beams without strengthening. For the maximum strength, an average increase in load capacity of 40.7 and $35.1 \%$ in the reference beams without strengthening (REF_0), respectively, was observed. Analyzing the yielding of the steel reinforcement of the exposed beams and considering the results obtained in the tests of the strengthened reference beams (REF_CFRP), it was noted that the elements maintained in laboratory environment and exposed to weathering presented a reduction of the average load of 12.6 and $8.4 \%$, respectively. It was also observed that the maximum force recorded in the strengthened beams exposed to weathering suffered a reduction of 6.4 and $10.0 \%$, respectively, when exposed to the environments previously presented. Finally, taking into account the maximum force recorded in the tests with the strengthened beams (Table 4), exposure to weather was more aggressive for the strengthening system, since its ultimate load was lower than that of the elements maintained in laboratory environment.

Concerning the failure load of the strengthened elements exposed to the environments, it was verified that there were no changes comparing it to the strengthened reference beams, presenting an almost fragile failure, preceded by pops and a lower load than verified for the strengthened reference beams, with the detachment of the CFRP sheet adhering to the concrete substrate (Figure 17).
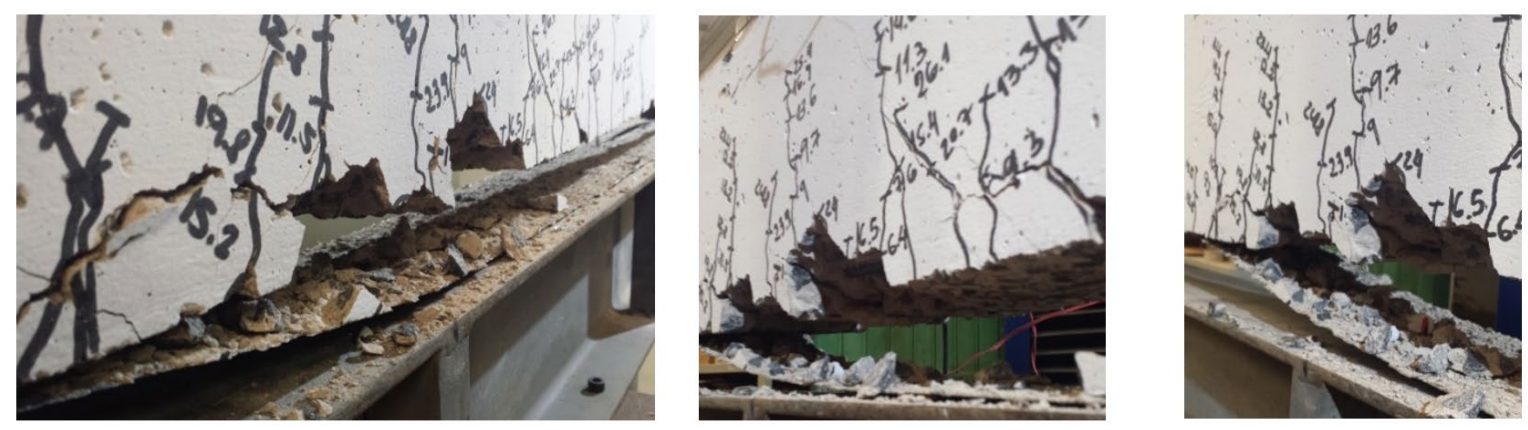

Figure 17. Verified failure mode on the strengthened beams

\section{CONCLUSIONS}

This work reports findings from an experimental program conducted to evaluate the efficiency of the EBR technique in increasing the load capacity of reinforced concrete beams strengthened in flexure with CFRP composites and also to evaluate the behavior of EBR-CFRP strengthening systems when exposed to weathering. Two exposure environments were adopted in this study (laboratory and weathering). Beams maintained in laboratory condition for 200 days, with and without strengthening, were considered as reference (REF), while the remaining beams were exposed to degradation environments and tested at the age of 380 days. The results obtained allowed for the following conclusions to be obtained:

- The efficiency of the EBR technique in increasing the load capacity of bending reinforced concrete beams with CFRP sheets was verified by means of significant increases in the load capacity of the strengthened elements. In relation to the steel reinforcement yielding, it was verified that the strengthening provided an increase in the load capacity corresponding to the beginning of the longitudinal strengthening yield and the maximum force of $19.7 \%$ and $50 \%$, respectively. In addition, there was a reduction in the average vertical displacement of $9.7 \%$ for strengthened reference beams, compared to those without strengthening, respectively, due to the reduction of cracking that the strengthening system promotes, restricting the reduction of the element's inertia;

- Analyzing the beginning of the steel yielding of the exposed beams and taking into account the results obtained in the tests of the strengthened reference beams (REF_CFRP) showed that the elements exposed to the laboratory environment and those exposed to weathering presented a reduction in the average load at steel yielding of 12.6 and $8.4 \%$, respectively. It is also possible to observe that the maximum force recorded in the strengthened beams exposed to these environments suffered a reduction of 6.4 and $10.0 \%$, respectively.

- Moreover, it was noted that the evolution of the curing time from 7 to 14 days of the primer and saturation epoxy resins maintained in laboratory environment resulted in statistically equivalent values, i.e., the curing time affected neither the mechanical properties of the specimens nor the behavior of the stress-deformation diagram. 
- Also, in relation to the epoxy resins maintained in laboratory environment, it was observed that the saturation resin presented losses of $23.8 \%$ and $19.2 \%$, respectively, in tensile strength and modulus of elasticity after 8 months of exposure in addition to an alteration in the failure mode, while the primer resin's properties remained statistically unchanged.

- The analysis of primer epoxy resin exposed to weathering was observed for the tests performed after 4 and 8 months of exposure reductions of 39 and $50 \%$ of tensile strength, respectively, in addition to the change in the failure mode of the specimens, while the modulus of elasticity resulted in statistically equivalent values.

- From the analysis of the saturation epoxy resin exposed for 4 and 8 months to the weathering, it was found that the tensile strength reduced by about 64 and $70 \%$, respectively, from the reference condition with 14 days of cure, and the failure mode changed from ductile to fragile without a plasticization interval. Regarding the modulus of elasticity, it was observed that the values were statistically similar up to 4 months of exposure, but after 8 months, a reduction of $18.2 \%$ in the modulus of elasticity was verified, as compared to the reference condition.

- The CFRP composites exposed to the laboratory environment and weathering showed no increase in their mechanical properties over the temporal evolution of the curing time from 7 to 14 days, and the results of the tests were statistically equivalent.

\section{ACKNOWLEDGEMENTS}

The authors wish to thank Polymer Laboratory of the Department of Materials Engineering (DEMa) and Structural Systems Laboratory (LSE) of the Federal University of São Carlos (UFSCar) for allowing us to conduct the tests for this research. We are also grateful to Coordination for the Improvement of Higher Education Personnel (CAPES) for their support in carrying out this study.

\section{REFERENCES}

[1] V. J. Ferrari, I. J. Padaratz, and D. D. Loriggio, "Reforço à flexão em vigas de concreto armado com manta de fibra de carbono: mecanismos de incremento de ancoragem," Acta Scientiarum, vol. 24, no. 6, pp. 1783-1791, 2002.

[2] Y. T. Obaidat, S. Heyden, O. Dahlblom, G. Abu-Farsakh, and Y. Abdel-Jawad, "Retrofitting of reinforced concrete beams using composite laminates," Constr. Build. Mater., vol. 25, pp. 591-597, 2010.

[3] A. P. Machado and B. A. Machado, Reforço de Estruturas de Concreto Armado com Sistemas Compostos FRP. São Paulo: Pini, 2015.

[4] M. Long, C. Djelal, S. Kesteloot, B. Bigourdan, P. Y. Le Gac, and J. Szulc, "Durability of CFRP concrete bonding in a marine environment," in Proc. Eur. Conf. Compos. Mater., Venice, Italy, 2012.

[5] J. A. Barros, "Materiais compósitos no reforço de estruturas de betão - parte I: propriedades e técnicas," Constr. Mag., vol. 22, pp. 26-35, 2007.

[6] J. R. Silva, "Reforço híbrido à flexão de vigas "T" de concreto armado com compósitos de fibras de carbono e fibras de vidro," Ph.D. dissertation, Dept. Struct. Civ. Constr., Univ. Brasilia, Brasília, 2014.

[7] C. Czaderski and U. Meier, "EBR strengthening technique for concrete long-term behaviour and historical survey," Polymers, vol. 10, no. 1, pp. 77-94, 2018.

[8] L. F. P. Juvandes, “Aplicações de compósitos FRP no reforço de estruturas,” in Proc. 1st Construct.Mater. Days, 2011, pp. 239-270. https://goo.gl/AGJQ42 (accessed Sep. 19, 2018).

[9] V. M. Karbhari, Durability of Composites for Civil Structural Applications. Cambridge: Woodhead, 2007.

[10] H. V. S. Gangarao, N. Taly, and P. V. Vijay, Reinforced Concrete Design with FRP Composites. Boca Raton: Taylor \& Francis, 2007.

[11] American Concrete Institute, Guide to Accelerated Conditioning Protocols for Durability Assessment of Internal and External FiberReinforced Polymer (FRP) Strengthening, ACI Committee 440.9R, 2015.

[12] ISIS, Durability of FRP Composites for Construction - The Canadian Network of Centers of Excellence on Intelligent Sensing for Innovative Structures (Educational Module 8). Manitoba, Canada: ISIS Canada Corp., 2006.

[13] M. M. Shokrieh and A. Bayat, "Effects of ultraviolet radiation on mechanical properties of glass/polyester composites," J. Compos. Mater., vol. 41, no. 20, pp. 2443-2455, 2007.

[14] M. C. Oliveira, "Análise do comportamento estrutural e durabilidade de pilares de concreto armado reforçados com mantas de GFRP,” M.S. thesis, Dept. Civ. Eng., Fed. Univ. São Carlos, São Carlos, 2019.

[15] J. Zhao, G. Cai, L. Cui, A. Si Larbi, and K. D. Tsavdaridis, "Deterioration of basic properties of the materials in FRP-strengthening RC structures under ultraviolet exposure," Polymers, vol. 9, no. 12, pp. 402, 2017. 
[16] S. M. Homam and S. A. Sheikh, "Durability of fiber reinforced polymers used in concrete structures," in Proc. 3rd Int. Conf. Adv. Mater. Bridges Struct., Ottawa, Ontario, Canada, 2000, pp. 751-758.

[17] M. I. Kabir, R. Shrestha, and B. Samali, "Experimental study on durability of CFRP-concrete bond subjected to temperature, humidity and outdoor environment," in Proc. 4th Asia-Pacific Conf. FRP in Struct., Melbourne, Australia, Dec. 2013, pp. 11-13.

[18] C. A. Alvares, J. L. Stape, P. C. Senthelas, J. L. M. Goncalves, and G. Sparovek, "Köppen's climate classification map for Brazil," Meteorol. Z., vol. 22, no. 6, pp. 711-728, 2013.

[19] Empresa Brasileira de Pesquisa Agropecuária. "Meteorologia.” Embrapa. http://www.cppse.embrapa.br/meteorologia/index.php?pg=caracterizacao (accessed Nov. 15, 2019).

[20] Wikipedia. https://pt.wikipedia.org/wiki/Clima_subtropical_\%C3\%BAmido\#/media/File:K\%C3\%B6ppen_World_Map_Cfa_and_Cwa_(Humid_ subtropical).svg (accessed July 16, 2019).

[21] Associação Brasileira de Normas Técnicas, Projeto de Estruturas de Concreto - Procedimento, NBR 6118, 2014.

[22] Associação Brasileira de Normas Técnicas, Concreto - Procedimento para Moldagem e Cura de Corpos de Prova, NBR 5738, 2015.

[23] D. C. Ferreira, “Avaliação da degradação de vigas reforçadas com FRP quando expostas ao intemperismo,” M.S. thesis, Dept. Civil Engineering, Fed. Univ. São Carlos, São Carlos, 2019.

[24] Associação Brasileira de Normas Técnicas, Materiais Metálicos - Ensaio de Tração, NBR 6892-1, 2018.

[25] P. Fernandes, P. Silva, L. Correia, and J. Sena-Cruz, "Durabilidade de um adesivo epóxi e um laminado de CFRP expostos a distintas condições ambientais," in Proc. 3rd Semin. Proj. Reinforce Concr. Struct. FRPs, 2015, pp. 8-14.

[26] A. D. Escobal, Caracterização da Degradação de Adesivos Estruturais Utilizados em Sistemas de Reforço de Estruturas de Concreto Armado. São Carlos: Sci. Initiation Res. Project, 2016.

[27] J. R. Cromwell, K. A. Harries, and B. M. Shahrooz, "Environmental durability of externally bonded FRP materials intended for repair of concrete structures," Constr. Build. Mater., vol. 25, no. 5, pp. 2528-2539, 2010.

[28] G. M. Dalfré, Estudo da Degradação da Aderência de Compósitos Colados a Superfícies de Concreto Armado Quando Submetidos a Ciclos de Umidade e Carbonatação, Universal Project, CNPq 483720/2013-5, 2016.

Author contributions: GMD, GAP: conceptualization, supervision, writing; DCF: experimental program, data analysis.

Editors: Maurício de Pina Ferreira, José Luiz Antunes de Oliveira e Sousa. 